\title{
Seropositivity among Blood Samples Drawn from Suspected Dengue Cases at a Tertiary Care Centre of Nepal: A Descriptive Cross-sectional Study
}

Rupesh Kumar Shreewastav, ${ }^{1}$ Manoj Kumar Thakur, ${ }^{2}$ Arambam Giridhari Singh'

'Department of Biochemistry, Nobel Medical College Teaching Hospital, Biratnagar, Morang, Nepal, ${ }^{2}$ Department of Medicine, Nobel Medical College Teaching Hospital, Biratnagar, Morang, Nepal.

\section{ABSTRACT}

Introduction: The cases of dengue fever have been reported more frequently in Nepal these days. The aim of this study was to find the prevalence of seropositivity among blood samples drawn from suspected dengue cases at a tertiary care centre of Nepal.

Methods: A descriptive cross-sectional study was conducted at a tertiary care hospital from $1^{\text {st }}$ June 2017 to $31^{\text {st }}$ October 2018 after getting approval from the Institutional Review Committee (Reference number: 23/2016). A total of 537 suspected dengue patients were selected for the study using convenience sampling. These dengue positive sera were assayed for their reactivity with Immunoglobulin $\mathrm{M}$ and Immunoglobulin $\mathrm{G}$ present in sera and synthetic peptides of dengue virus by enzyme linked immunosorbent assay. Data was entered and analysed in Microsoft Excel 2016. Point estimate at $95 \%$ Confidence Interval was calculated along with frequency, percentage, mean and standard deviation.

Results: Among 537 suspected dengue cases, the seropositivity for dengue was found in 124 (23.09\%) (19.52-26.65 at 95\% Confidence Interval) of the serum.

Conclusions: The present study revealed that dengue was more prevalent in our setting compared to similar studies. All the synthetic peptides showed reactivity with dengue-positive sera with maximum reactivity shown by RR2 peptide. In dengue-positive sera, RR2 peptide of dengue virus identified more Immunoglobulin M than Immunoglobulin G.

Keywords: dengue; IgG; IgM; tertiary care.

\section{INTRODUCTION}

Dengue fever is a viral disease spread by mosquito of Flaviviridae family. ${ }^{1,2}$ Antigenically, four different serotypes of the dengue virus with $65 \%$ genomic similarity exist. ${ }^{3,4}$ Commercially available kits use mixes of inactivated viral preparations or recombinant envelope proteins, so detection of anti-dengue antibodies is problematic. ${ }^{5}$

The envelope (E) protein and non-structural protein (NS1) encoded by dengue virus are very important in the pathogenicity of dengue virus infection and are highly conserved in all strains. ${ }^{6}$ Hence, these two proteins were selected to identify epitopes for detecting anti $\lg M$ and $\lg G$ antibodies. These epitopes were synthesised as linear peptides with the help of
DNA star approach. ${ }^{7}$

The aim of this study was to find the prevalence of seropositivity among blood samples drawn from suspected dengue cases.

\section{METHODS}

This was a descriptive cross-sectional study carried out at a tertiary care hospital from $1^{\text {st }}$ June 2017 to $31^{\text {st }}$ October 2018 after getting approval from the

Correspondence: $\mathrm{Dr}$ Rupesh Kumar Shreewastav, Department of Biochemistry, Nobel Medical College Teaching Hospital, Biratnagar, Morang, Nepal. Email: rupeshaiims4@gmail. com, Phone: +977-9841864446. 
Institutional Review Committee (Reference number: 23/2016) of Nobel Medical College and Teaching Hospital (NMCTH). All the patients, who presented to the emergency and medicine departments of NMCTH, suspected with dengue were the study population. Convenience sampling was done. The sample size was calculated by using the formula:

$$
\begin{aligned}
\mathrm{n} & =\mathrm{Z}^{2} \times \mathrm{p} \times \mathrm{q} / \mathrm{e}^{2} \\
& =(1.96)^{2} \times 0.5 \times(1-0.5) / 0.05^{2} \\
& =385
\end{aligned}
$$

Where,

$\mathrm{n}=$ minimum required sample size

$\mathrm{Z}=\mathbf{1 . 9 6}$ at $95 \%$ Confidence Interval $(\mathrm{Cl})$

$\mathrm{p}=$ prevalence taken as $50 \%$ for maximum sample size $q=1-p$

$\mathrm{e}=$ margin of error, $5 \%$

The sample size calculated was 385. However, we have included 537 patient's samples from Clinical laboratory services, NMCTH. Dengue-positive serum was diagnosed based on the NS1 antigen in an immunochromatographic card test kit. These denguepositive sera were assayed for their reactivity with IgM and IgG present in the sera and synthetic peptides (RR2, RR3, RR4, RR5, RR6, RR8) of dengue virus by ELISA technique.

At $\mathrm{PH} 9.6,400 \mathrm{ng}$ of peptide was dissolved in $100 \mathrm{ml}$ of $0.05 \mathrm{M}$ carbonate bicarbonate buffer. At $37^{\circ} \mathrm{C}$ for 4 hours, the dissolved peptide was coated in the wells of microtiter plates. The wells were rinsed three times with PBS $/ 0.05 \%$ Tween 20 (PBS-T) before being blocked overnight at $4^{\circ} \mathrm{C}$ with $200 \mathrm{ml}$ blocking solution (five percent skimmed milk powder in PBS-T). After washing the plates, Chikungunya (CHIKV), DENV, and negative sera (1:100 dilutions) were added to duplicate wells and incubated at $37^{\circ} \mathrm{C}$ for two hours. Antigen-antibody complexes were identified using HRP-conjugated goat anti human $\operatorname{lgM} / \operatorname{lgG}$ antibodies (1:2000). The plates were cleaned as before, and colour was developed with a TMB-containing substrate solution. Adding 100 micro litre of $1 \mathrm{~N}$ sulphuric acid and optically stopping the reaction and optical density (OD) was measured at $492 \mathrm{~nm}$. The synthetic peptide RR2 was tested for nondengue viral reactivity using CHIKV sera. The sera that were neither IgM nor IgG DNEV positive were used as a negative control.

To test the diagnostic efficiency of peptide with patient sera, a cutoff value for optical density (OD) was calculated. The cutoff values for peptide were in the range of $0.31-0.34$ based on the seroreactivity of 18 healthy human sera tested for IgM. We looked at the seroreactivity of all dengue positive and 20 chikungunya positive patient sera based on the cutoff value for this peptide. The computed cutoff value for $\operatorname{lgG}$ was in the range of $0.33-0.38$. There was no seroreactivity with any of the peptides in any of the 20 chikungunya positive and healthy sera. When the OD Value of a human blood sample was found to be greater than the cut-off value when tested for IgM and IgG in an ELISA, it was declared reactive with synthetic peptides.

All the peptides were synthesised, purified and authenticated in the All India Institute of Medical Sciences (AIIMS), New Delhi. The Peptide was selected on hydrophilicity, secondary structures, antigenicity index, amphipathicity, using Bcepred/DNA star software for $B$ cell and $T$ cell prediction. These peptides were synthesised by Fluorenylmethoxycarbonyl Chemistry. ${ }^{7}$ The readymade form of these synthetic peptides were gifted to us by AlIMS to carry out the study in Nepal.

The data was entered and analysed in Microsoft Excel 2016. Point estimate at $95 \%$ Confidence Interval was calculated along with frequency, percentage, mean and standard deviation.

\section{RESULTS}

Among 537 suspected dengue cases, the seropositivity for dengue was found in 124 (23.09\%) (19.52-26.65 at $95 \%$ Confidence Interval) of the serum. Out of 124 dengue positive patients, $71(57.3 \%)$ were male and $53(42.7 \%)$ were female. The mean age of dengue positive patients was $41 \pm 19.6$ year with a range from 5 to 83 years. The maximum number of dengue positive patients was $47(37.9 \%)$ in the $21-40$ years age group.

\begin{tabular}{|c|c|}
\hline Characteristics & n (\%) \\
\hline \multicolumn{2}{|l|}{ Gender } \\
\hline Male & $71(57.3)$ \\
\hline Female & $53(42.7)$ \\
\hline \multicolumn{2}{|l|}{ Age (years) } \\
\hline$\leq 20$ & $18(14.51)$ \\
\hline $21-40$ & 47 (37.9) \\
\hline $41-60$ & $36(29.03)$ \\
\hline$\geq 60$ & $23(18.54)$ \\
\hline
\end{tabular}
Thirty-six (29.03\%) of patients were dengue positive in the 41-60 years age group (Table 1).

All peptides responded with dengue sera, according to an analysis of 124 dengue positive sera verified for NS1 using a determined cutoff value. RR2 detected IgM in 100 (80.6\%) sera, RR3 in 93 (75\%) sera, RR4 in $96(77.41 \%)$ sera, RR5 in $64(51.6 \%)$ sera, RR6 in $86(69.35 \%)$ sera, and RR8 in $90(72.58 \%)$ sera. IgG antibodies against synthetic peptides were found in several of the dengue positive samples. IgG was identified by RR2 in 60 (48.38\%), RR3 in 64 (51.6\%), RR4 in 57 (45.96\%), RR5 in 53 (42.74\%), RR6 in 50 (40.32\%), 
and RR8 in 51 (41.12\%) sera (Table 2).

\begin{tabular}{|c|c|c|}
\hline $\begin{array}{l}\text { Table } 2 . \\
\text { and RR8 } \\
(n=124)\end{array}$ & $\begin{array}{l}\text { eactivity of } R \\
\text { with dengu }\end{array}$ & $\begin{array}{l}\text { RR4, RR5 } \\
\text { e serum }\end{array}$ \\
\hline Peptides & Antibodies & n (\%) \\
\hline RR2 & $\lg M$ & $100(80.6)$ \\
\hline & $\lg G$ & $60(48.38)$ \\
\hline RR3 & $\lg M$ & $93(75)$ \\
\hline & $\lg G$ & $64(51.6)$ \\
\hline RR4 & $\lg M$ & $96(77.41)$ \\
\hline & $\lg G$ & 57 (45.96) \\
\hline RR5 & $\lg M$ & $64(51.6)$ \\
\hline & $\lg G$ & $53(42.74)$ \\
\hline RR6 & $\lg M$ & $86(69.35)$ \\
\hline & $\lg G$ & $50(40.32)$ \\
\hline RR8 & $\lg M$ & 90 (72.58) \\
\hline & $\lg G$ & $51(41.12)$ \\
\hline
\end{tabular}

The samples having OD more than the cut-off values were considered reactive. With RR2 peptide the dengue positive sera, the maximum OD obtained was 3.3 and the minimum OD value was 0.5 (Figure 1). Similarly, the $\lg G$ dengue positive sera were also reacted with $R R 2$ peptide and found that 60 samples were considered reactive. The maximum $O D$ value obtained was 2.4 and minimum was 0.46 (Figure 2). The data for each sera OD when reacted with other peptides while detecting $\lg \mathrm{M}$ or $\lg \mathrm{G}$ are not shown.

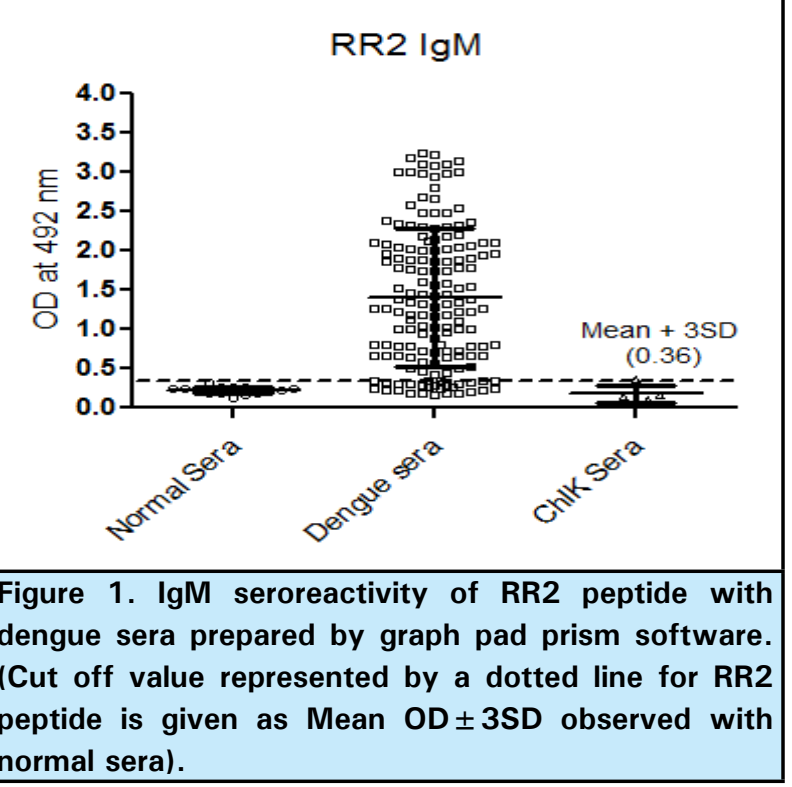

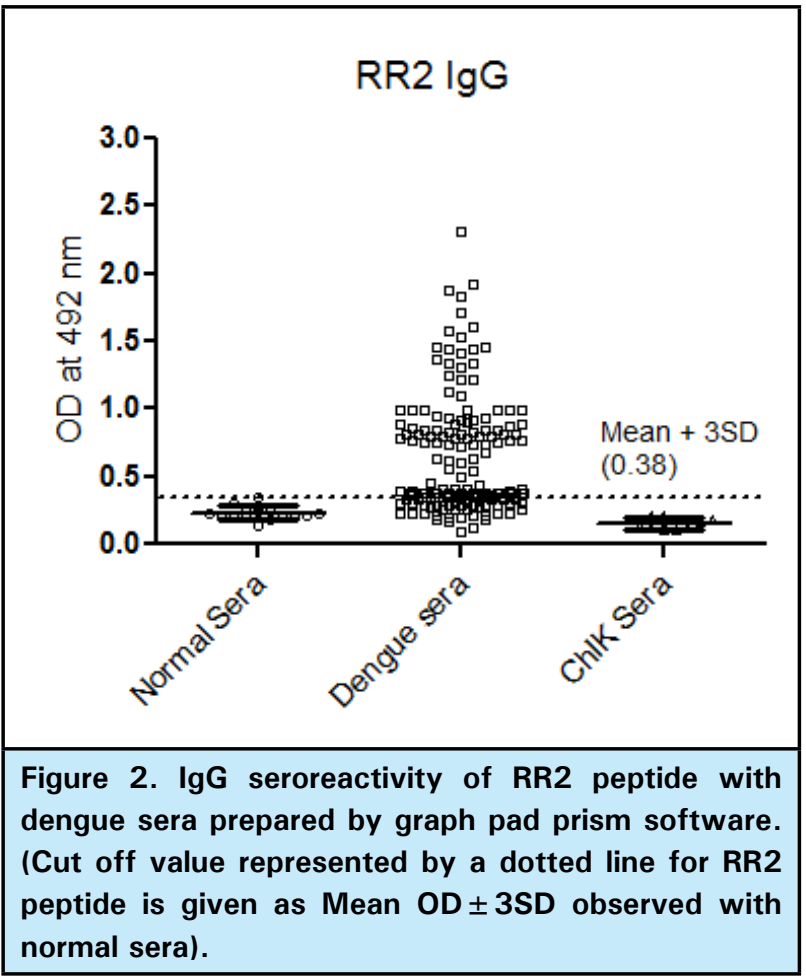

\section{DISCUSSION}

Dengue viral infection is a serious health concern. Dengue infection is difficult to control because it necessitates effective vector control as well as early, precise, and strain-specific diagnosis. Dengue fever diagnosis has remained a challenge for disease treatment, particularly in developing countries like Nepal. Therefore, we have made an attempt to study the sero-reactivity of synthetic antigenic peptide of dengue virus with dengue positive sera for the first time in Nepal. This peptide can be used as a tool for the diagnosis of dengue in future. The seropositivity was found in $23.09 \%$ of the serum in the present study. $\mathrm{Rijal} \mathrm{KR}$, et al. had reported the prevalence of dengue in Nepal in a study, which showed that in 2018, case incidence was about five times higher than in 2016 (incidence rate ratio (IRR): 4.8; $95 \%$ Confidence Interval (CI) 1.5-15.3) and more than 140 times higher in 2019 (IRR: 141.6; 95 \% Confidence Interval 45.8-438.4). ${ }^{8} \mathrm{~A}$ similar finding was reported in a study carried out in Western Uttar Pradesh, India, which revealed that $23 \%$ patients were found seropositive either by NS1 Ag or IgM Ab ELISA. ${ }^{9}$ In the present study, among dengue positive patients, 71 (57.3\%) were male and 53 (42.7\%) were female with mean age of 41 year ranging from five to 83 years. Kumar $M$, et al. reported that among all dengue seropositive cases in Uttar Pradesh, India , the proportion of male was higher over female with the ratio of $(M: F)$ being 1.54:1 with mean age \pm standard deviation of all patients was $27.16 \pm 14.82$ years. ${ }^{9} A$ study conducted in Pakistan had reported that among 
Shreewastav et al. Seropositivity among Blood Samples Drawn from Suspected Dengue Cases at a Tertiary Care Centre of Nepal...

all dengue positive patients, $(72.9 \%)$ were males and $(27.1 \%)$ were females. The patients ranged in age from 6 to 90 years old, with a median age of $30 .{ }^{10}$ We have observed in this study that the maximum number of dengue positive patients was $47(37.9 \%)$ in $21-40$ years age group, whereas the study conducted by Raza FA, et al. reported that among dengue positive cases, the maximum $48.5 \%$ of dengue positive patients were of $17-30$ years old. ${ }^{10}$

In the present study, RR2 peptide detected IgM in $80.6 \%$ sera and IgG in $48.38 \%$ sera. RR3 detected IgM in 93 (75\%) sera, RR4 in 96 (77.41\%) sera, RR5 in 64 (51.6\%) sera, RR6 in 86 (69.35\%) sera, and RR8 in 90 (72.58\%) sera. IgG was identified by RR2 in 60 (48.38\%), RR3 in 64 (51.6\%), RR4 in 57 (45.96\%), RR5 in 53 (42.74\%), RR6 in 50 (40.32\%), and RR8 in 51 (41.12\%) sera. In one study, it has been reported that the synthetic peptides detected antibodies in Dengue virus positive serum samples using the predicted epitopes in an indirect ELISA. ${ }^{11}$ In another similar study carried in All India Institute of Medical Sciences, New Delhi demonstrated that synthetic antigenic peptides detected $\lg M$ and IgG in Dengue positive sera. Many synthetic peptides were used in combination to form multiple antigenic peptides $(1,2,3)$. Multiple antigenic peptide one detected $\lg \mathrm{M}$ in $96.81 \%$ of sera and $\lg \mathrm{G}$ in $68.15 \%$ of sera. Multiple antigenic peptide two discovered IgM positive sera in $94.90 \%$ of cases and IgG positive sera in $59.23 \%$ of cases. Multiple antigenic peptide three also found $\lg \mathrm{M}$ and $\lg$ positive sera in $96.17 \%$ and $59.87 \%$ of cases, respectively. ${ }^{7}$ Mazumdar $\mathrm{R}$, et al. detected dengue specific IgG with some synthetic continuous peptides, spanning over amino acids at positions 51-65, 71-90, 131-170, 196-210, and 246-260 from $E$ protein of Dengue virus-3. ${ }^{12}$ Honda ER, et al. had reported in his study that NS1 specific $\lg G, \lg M$ and $\lg \mathrm{A}$ antibodies are found in the sera of patients with dengue fever and dengue hemorrhagic fever. ${ }^{13}$ In many of the studies, these chemically synthesised peptides have been studied as a alternate source of antigen for diagnosis. ${ }^{14} \mathrm{RR} 2$ synthetic peptide of dengue virus was reactive with dengue positive sera in the present study, which makes it suitable for the easy and accurate diagnosis of dengue infection in developing country like Nepal, where dengue is endemic. The study also demonstrates that such synthetic peptide can be used easily for dengue diagnosis in the set up of hospitals in countries like Nepal.

There are some limitations of the present study. Dengue-positive patients had been included from one study centre. The results would have been interpreted more reasonably if the more dengue-positive samples would have been enrolled from different epidemic regions of Nepal.

\section{CONCLUSIONS}

The prevalence of dengue was higher in our setting as compared to other similar studies. Among all patients, dengue positivity was found to be more in male than females. The maximum number of patients were reported from the middle younger age group. All the synthetic peptides of dengue virus had shown their reactivity with immunoglobulin $M$ and immunoglobulin $G$ present in the dengue-positive sera. The synthetic peptides detected more IgM than $\lg \mathrm{G}$ in all dengue-positive sera. Among all the synthetic peptides of dengue virus, RR2 peptide detected more $\lg \mathrm{M}$ and $\lg \mathrm{G}$ than other peptides.

\section{Conflict of Interest: None.}

\section{REFERENCES}

1. Back AT, Lundkvist A. Dengue viruses - an overview. Infect Ecol Epidemiol. 2013 Aug 30;3. [․ubMed | Full Text | DOI]

2. Westaway EG, Brinton MA, Gaidamovich SYa, Horzinek MC, Igarashi A, Kariainen L, et al. Flaviviridae. Intervirology. 1985;24(4):183-92. [ㅁubMed | Full Text | DOI]

3. Gubler DJ. Dengue and dengue hemorrhagic fever. Clin Microbiol Rev. 1998 Jul;11(3):480-96. [라bMed | Full Text | $\underline{\mathrm{DOI}}]$

4. Guzman MG, Halstead SB, Artsob H, Buchy P, Farrar J, Gubler DJ, et al. Dengue: a continuing global threat. Nat Rev Microbiol. 2010 Dec;8(12 Suppl):S7-16. [PubMed | Full Text | $\underline{\mathrm{DOI}}]$

5. Swaminathan S, Khanna N. Dengue: recent advances in biology and current status of translational research. Curr Mol Med. 2009 Mar;9(2):152-73. [라Med | Full Text | DOI]

6. Nasar S, Rashid N, Iftikhar S. Dengue proteins with their role in pathogenesis, and strategies for developing an effective anti-dengue treatment: A review. J Med Virol. 2020 Aug;92(8):941-55. [PubMed | Full Text | DOI]

7. Rai R, Dubey S, Santosh KV, Biswas A, Mehrotra V, Rao DN. Design and synthesis of multiple antigenic peptides and their application for dengue diagnosis. Biologicals. 2017 Sep;49:81-5. [PubMed | Full Text | DOI]

8. Rijal KR, Adhikari B, Ghimire B, Dhungel B, Pyakurel UR, Shah $\mathrm{P}$, et al. Epidemiology of dengue virus infections in Nepal, 2006-2019. Infect Dis Poverty. 2021 Apr 15;10(1):52. [PubMed | Full Text | DOI]

9. Kumar M, Verma RK, Mishra B. Prevalence of Dengue Fever in Western Uttar Pradesh, India: A Gender-Based Study. Int J Appl Basic Med Res. 2020 Jan-Mar;10(1):8-11. [PubMed | Full Text | DOI]

10. Raza FA, Rehman Su, Khalid R, Ahmad J, Ashraf S, Iqbal M, et al. Demographic and clinico-epidemiological features of 
dengue fever in Faisalabad, Pakistan. PLoS One. 2014 Mar 3;9(3):e89868. [PubMed | Full Text | DOI]

11. Guzman MG, Kouri G. Dengue diagnosis, advances and

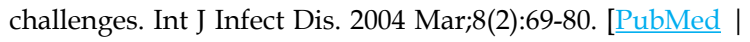
Full Text | DOI]

12. Mazumder R, Hu ZZ, Vinayaka CR, Sagripanti JL, Frost SD, Kosakovsky Pond SL, et al. Computational analysis and identification of amino acid sites in dengue $\mathrm{E}$ proteins relevant to development of diagnostics and vaccines. Virus Genes. 2007 Oct;35(2):175-86. [uued | Full Text | DOI]
13. Honda ER, Zanchi F, Rios K, Lira E, DeusileneVieira, da Silva $\mathrm{LH}$, et al. Design and heterologous expression of dengue virus envelope protein (E) peptides and their use for serological diagnosis. J Virol Methods. 2012 Dec;186(1-2):55-61. [PubMed | Full Text | DOI]

14. Kowalczyk W, Monso M, de la Torre BG, Andreu D. Synthesis of multiple antigenic peptides (MAPs)-strategies and limitations. J Pept Sci. 2011 Apr;17(4):247-51. [PubMed | Full Text | DOI]

This work is licensed under a Creative Commons Attribution 4.0 International License. The images or other third party material in this article are included in the article's Creative Commons license, unless indicated otherwise in the credit line; if the material is not included under the Creative Commons license, users will need to obtain permission from the license holder to reproduce the material. To view a copy of this license, visit http://creativecommons.org/licenses/by/4.0/ 